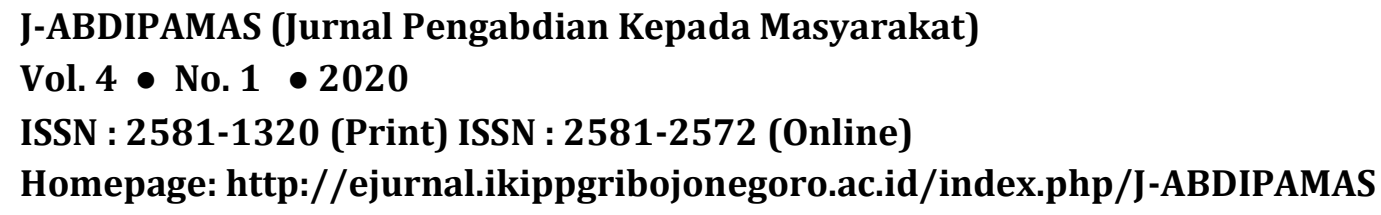

ISSN : 2581-1320 (Print) ISSN : 2581-2572 (Online)

Homepage: http://ejurnal.ikippgribojonegoro.ac.id/index.php/J-ABDIPAMAS

\title{
PEMANFAATAN BOTOL BEKAS MENJADI TEMPAT PENSIL YANG BERNILAI SENI DAN EKONOMIS DI KELAS V SDN SAMBERAN KECAMATAN KANOR KABUPATEN BOJONEGORO
}

\author{
Neneng Rika Jazilatul Kholidah ${ }^{1}$, Sarjono ${ }^{2}$, Yuniarta ita Purnama ${ }^{3}$, Yupita ${ }^{4}$ \\ ${ }^{1}$ IKIP PGRI BOJONEGORO Email: jazilarika@yahoo.co.id \\ ${ }^{2}$ IKIP PGRI BOJONEGORO Email: Sarjono-1956@yahoo.com \\ ${ }^{3}$ IKIP PGRI BOJONEGORO Email: niar.purnama@gmail.com \\ 4IKIP PGRI BOJONEGORO Email : yupitapita30@gmail.com
}

\begin{abstract}
The purpose of this community service program is the utilization of bottles become an aesthetic and economic pancil case at State Elementary School Samberan Kanor Bojonegoro to reduce the negative effect of plastic waste. The aims of this program are: (1) to give the knowledge and training for State Elementary School Samberan students about the utilization of secondhand goods to be beneficial pancil cases; (2) to improve the creativities of State Elementary School Samberan students in the utilization of plastic bottle; (3) to give the creative ideas to students, So they can follow the creative contest about recycle plastic bottle; (4) to decrease the pollution by recycle the plastic secondhand goods. To reach the aims, we used the active, creative, and joyful method. The data was gained by observation, lecture, question-answer, and demonstration. The result showed that the students become more enthusiastic in joining this community service program. They create the pancil case from recycling bottle That would reduce the use of plastics and the negative effect of plastics waste.
\end{abstract}

Keywords: Recycling bottle, pancil case, art and economics.

\begin{abstract}
ABSTRAK
Tujuan dari Pengabdian Kepada Masyarakat (PKM) ini adalah Pemanfaatan Botol Bekas Menjadi Tempat Pensil Yang Bernilai Seni Dan Ekonomis di SDN Samberan Kecamatan Kanor Kabupaten Bojonegoro, untuk mengurangi dampak negatif sampah plastik. Tujuan dari program ini adalah : (1) Untuk memberikan pengetahuan dan pelatihan kepada siswa-siswi SDN Samberan mengenai pemanfaatan barang bekas menjadi tempat pensil yang bermanfaat; (2) Untuk Meningkatkan kreativitas siswa-siswi SDN Samberan dalam memanfaatkan botol plastik.(3) Untuk memberikan ide kreatif kepada siswa sehingga mereka dapat mengikuti ajang kreatifitas tentangan penggunaan ulang botol plasti. (4) Mengurangi pencemaran lingkungan dengan cara memanfaatkan barang-barang plastik bekas. Untuk mencapai tujuan tersebut digunakan metode yang aktif, kreatif dan menyenangkan. Data dikumpulkan degan menggunakan observasi, ceramah, tanya jawab, dan demonstrasi. Hasilnya menunjukkan bahwa siswa menjadi lebih antusias mengikuti program pengabdian kepada masyarakat ini. Mereka menghasilkan tempat pensil dari botol bekas yang bisa mengurangi penggunaan plastik dan mengurangi dampak negatif dari sampah plastik.
\end{abstract}

Kata Kunci: Botol bekas, tempat pensil, seni dan ekonomis. 


\section{PENDAHULUAN}

Pada jenjang sekolah dasar ( SD) merupakan tempat untuk anak-anak belajar sekaligus bermain, dikarenakan pada sekolah dasar ini anak akan meniru perilaku yang lakukan orang-orang yang ada disekitarnya mulai dari teman sebaya hingga orangorang dewasa dan juga akan meniru orang-orang yang dianggap dekat dengan dirinya, menjadi masalah jika orang-orang yang ada dilingkungan dan orang -orang yang dianggap dekat mampu memberikan sebuah contoh yang baik tapi bagaimana jika mereka tidak memberikan contoh yang kurang baik bahkan sampai tidak baik maka semua akan berdampak pada perilaku seorang anak. Dalam hal ini maka sekolah dasar menjadi sebuah tempat pendidikan yang berpotensi mengembangkan keinginan siswa yang dimana memberikan dampak positif dari semua kegiatan yang diajarkan di sekolah termasuk kegiatan kreativitas dalam memanfaatkan barang bekas yang ada disekitar. Permasalahan tentang sampah bukan menjadi hal yang baru namun masalah sampah tidak akan pernah ada habisnya, bahkan banyak produk-produk yang dibuat dan dinikmati secara instan membuat sampah semakin hari semakin banyak dan hal ini seharusnya menjadi tugas masyarakat namun tidak semua masyarakat sadar akan hal itu sehingga dengan begitu saja sampah tidak menjadi urusan nomor satu tapi menjadi hal yang disepelekan, dalam hal ini yang menjadi sorotan adalah sampah plastik yang berserakan dimana-mana dan menumpuk sehingga tanpa memikirkan dampak apa yang akan terjadi jika sampah plastik dibiarkan begitu saja.

Menurut Kementrian lingkungan hidup, pada tahun 2018 sampah yang dihasilkan mencapai 66,8 juta ton atau setiap orang dalam sehari mencapai $0,7 \mathrm{~kg}$ sampah. Plastik dan barang yang dapat dikelola oleh pemerintah hanya sebanyak 15\% atau 10,02 juta ton. Hal ini menunjukan bahwa sebanyak 56, 78 juta ton sampah tidak dapat dikelola dan masuk ke dalam tempat pembuangan akhir (TPA).

Sampah menurut Undang-Undang Republik Indonesia No. 18 Tahun 2008 adalah sisa kegiatan sehari-hari manusia dan/atau proses alam yang berbentuk padat. Sampah adalah barang yang dianggap sudah tidak terpakai dan dibuang oleh pemilik/pemakai sebelumnya,tetapi bagi sebagian orang masih bias dipakai jika dikelola dengan prosedur yang benar (Nugroho, 2013). Sampah plastik berdampak negatif terhadap lingkungan karenatidak dapat terurai dengan cepat dan dapat menurunkan kesuburan tanah. Sampah plastik yang dibuang sembarangan juga dapat menyumbat saluran drainase, selokan dan sungai sehingga menyebabkan banjir selain itu sampah plastik yang dibakar bisa mengeluarkan zat-zat yang berbahaya bagi kesehatan manusia(Surono, 2013).

Pertambahan jumlah penduduk juga dapat menyebabkan peningkatan jumlah sampah, karena setiap hari menusia membutuhkan mankanan, dan yang pasti menghasilkan limbah rumah tangga berupa sampah (Zulkarnain, Farhan, 2019).

Sampah plastik dapat bertahan hingga bertahun-tahun sehingga menyebabkan pencemaran terhadap lingkungan. Sampah plastik berbahaya jika dibakar karena menghasilkan gas yang akan mencemari udara dan membahayakan pernafasan manusia, dan jika sampah plastik ditimbun dalam tanah maka akan mencemari tanah dan air (Karuniastuti, 6-14: 2016). 
Terlihat jelas bahwa masyarakat saat ini belum bisa menghilangkan kebiasaan memakai bahan dari plastik dalam kehidupan sehari-harinya namun setidaknya masyarakat bisa mengurangi penggunaan plastik atau memanfaatkan barang-barang bekas yang berasal dari plastik menjadi barang yang bisa dimanfaatkan kembali.

Berdasarkan bahan asalnya sampah dibagi menjadi dua jenis yaitu sampah organik dan anorganik :

\section{Sampah Organik}

Sampah yaitu buangan sisa makanan misalnya daging, buah, sayuran dsb. Contoh sampah dari zat organik adalah : potongan-potongan/plat-plat dari logam, berbagai jenis batu-batuan, pecahan-pecahan gelas, tulang, belulang, dll. Sampah jenis ini, melihat fisiknya keras maka baik untuk peninggian tanah rendah atau dapat pula untuk memperluas jaln setapak. Tetapi bila rajin mengusahakannya sampah dari logam dapat kembali dilebur untuk dijadikan barang yang berguna, batu-batuan untuk mengurung tanah yang rendah atau memperkeras jalan setapak, pecahan gelas dapat dilebur kembali dan dijadikan barang-barang berguna, dan tulang belulang bila dihaluskan(bila diporoses)dapat untuk pupuk dan lain-lain.

2. Sampah anorganik

Sempah anorganik yaitu sisa material sintesis misalnya plastik, kertas, logam , kaca, keramik dan sebagainya (Sucipto,2009).

Dalam hal ini menjadi suatu peluang bagi tim PKM untuk memberdayakan sampah yakni botol bekas air minum melalui sebuah kreativitas tempat pensil bagi siswa SDN Samberan khususnya kelas V dimana memalui kreativitas tersebut mampu menyalurkan imajinasi siswa untuk berkreasi, bahkan nantinya kami berharap mereka selalu memunculkan sebuah ide-ide baru dalam hal memberdayakan sampah menjadi barang yang berguna.

SDN Samberan memilikivisi terwujudnya insan cerdas berprestasi dan terampil berdasarkan IMTAQ dan IPTEK berkarakter dan berbudaya lokal. SedangkanmisiSD Negeri Samberanvadalah meningkatkan keunggulan dalam pengembangan kurikulum, meningkatkan lingkungan belajar yang rekreatif, edukatif, dan religius,meningkatkan sumber daya pendidik yang profesional, mengembangkan seni budaya yang islami dan temporer, mengembangkan keterampilan (life skill) yang relevan dengan ciri khas Desa Samberan, melaksanakan kegiatan pengembangan diri untuk mengembangkan bakat dan potensi non akademik peserta didik, melaksanakan manajemen sekolah yang transparan, partisipatif dan akuntabel (MBS).

\section{METODE PELAKSANAAN}

Pemanfaatan sampah melalui kreativitas botol bekas dan diubah menjadi tempat pensil atau barang apapun yang bernilai seni adalah salah satu cara pemerintah dan masyarakat untuk mengurangi dampak negatif dari sampah plastik. Menciptakan budaya cinta terhadap lingkungan dimulai dari dini sangatlah penting bahkan juga sangat perlu. Pada jenjang sekolah dasar adalah target pertama, karena mereka berkemungkinan memiliki kemampuan yang luar biasa dan memiliki jiwa terhadap seni 
dalam memanfaatkan barang bekas sehingga mampu mengurangi dampak negatif dari sampah plastik.

Cara untuk mengukur kepedulian siswa terhadap lingkungan adalah dengan cara melatih mereka untuk memanfaatkan barang bekas melalui sebuah kreativitas bernilai seni yakni mengubah botol bekas menjadi tempat pensil, dimana selain siswa pandai akan pentingnya pelajaran di sekolah namun siswa harus di gali nilai seninya melalui sebuah kreativitas, dimana sebuah seni atau keindahan juga diperlukan untuk menambah jiwa kepercayaan diri seorang siswa. Pada pertemuan dilakukan metode ceramah, demonstrasi, dan pelatihan. Kegiatan yan dilakukan dalam mencapai tujuan pengabdian kepada masyarakat adalah : Persiapan, Sebelum melakukan Pengabdian Kepada Masyarakat, kami Tim PKM melakukan survey lokasi dan melakukan perijinan kepada Kepala Sekolah SDN Samberan Kecamatan Kanor mengenai pelaksanaan kegiatan. Pelaksanaan, Pelatihan pembuatan tempat pensil dari barang bekas melalui ceramah, demonstrasi, dan tanya jawab.

\section{Metode yang Digunakan}

Ceramah digunakan untuk menyampaikan kepada siswa bahwa sampah plastik yang dibuang khususnya botol bekas bisa dipakai kembali menjadi tempat pensil dan mampu mengurangi dampak negatif dari sampah plastik, demonstrasi digunakan untuk memberikan keterampilan kepada siswa secara langsung mengenai proses pembuatan tempat pensil, tanya jawab digunakan untuk siswa yang belum memahami dalam pembuatan tempat pensil dari barang bekas, pelatihan pembuatan kotak pensil ditujukan kepada seluruh sisw dan Evaluasi

\section{HASIL DAN PEMBAHASAN}

Kreativitas merupakan kemampuan seseorang untuk menghasilkan komposisi, produk atau gagasan apa saja yang ada dasarnya baru dan sebelumnya tidak dikenal pembuatnya. Dapat mencakup pembentukan pola baru dan gabungan informasi yang diperoleh dari pengalaman sebelumnya dan mempunyai maksud dan tujuan yang ditentukan. Dapat berupa produk seni, produk ilmiah, maupun produk yang lain (Familia, 2010). Kreativitas dari botol bekas bukan merupakan hal yang baru, namun bagi mereka yang belum pernah mengubah botol bekas menjadi sebuah kreativitas adalah sesuatu yang baru dan akan menjadi hal yang sangat mengesankan.

Kreativitas dari botol bekas direspon oleh siswa dengan sangat antusias saat tim PKM (Pengabdian Kepada Masyarakat) memberikan ceramah tentang pentingnya menjaga lingkungan dari dampak negatif sampah plastik. Lalu tim membagi menjadi 4 kelompok yang masing-masing beranggotakan 6 orang dari jumlah siswa 24 yang ada dikelas V (lima). Masing-masing kelompok oleh Tim PKM diberikan bahan-bahan dalam pembuatan tempat pensil. 


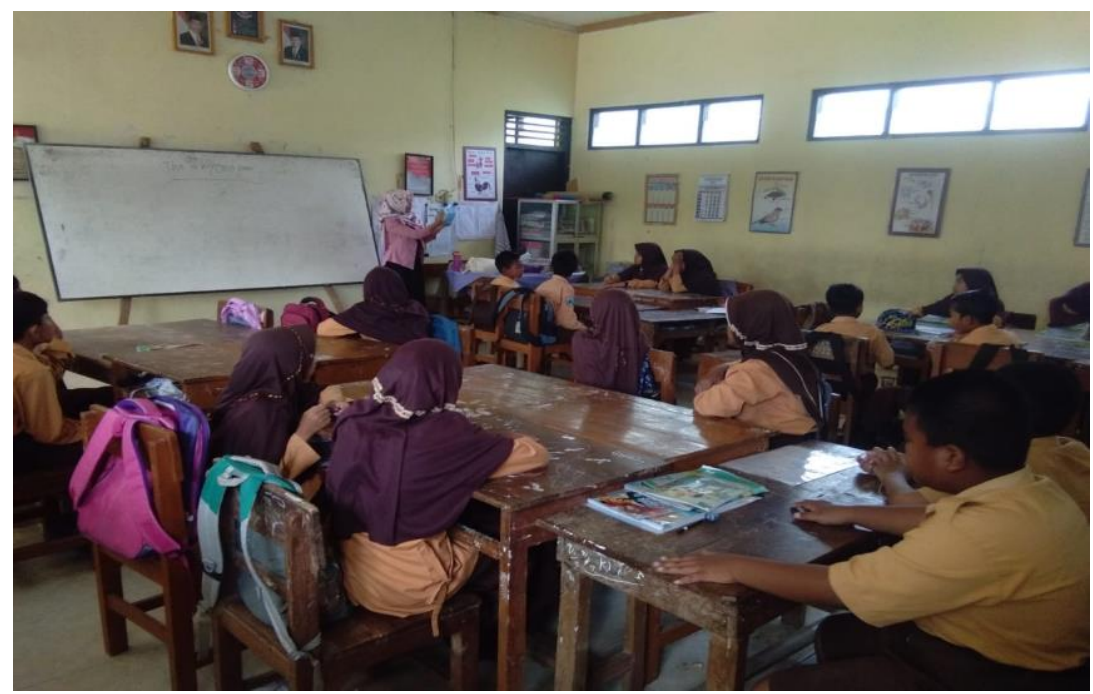

Gambar 1. Antusias siswa saat mendengarkan ceramah

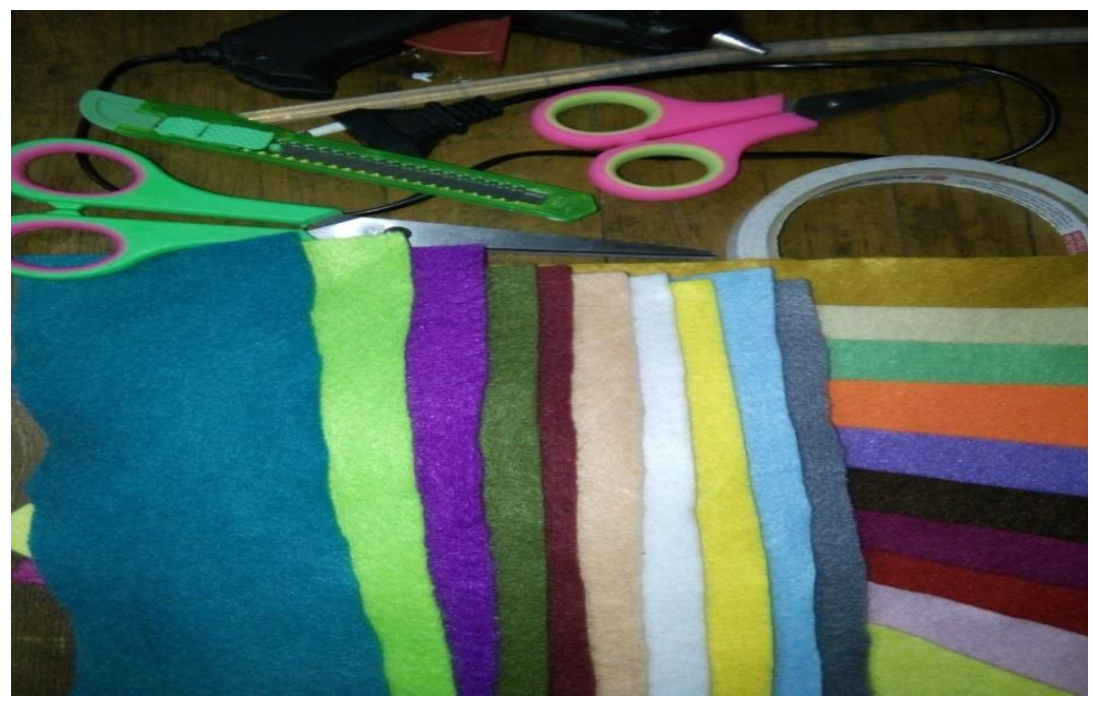

Gambar 2. Bahan dan alat untuk menghias tempat pensil

Tim PKM memberikan kebebasan kepada masing-masing kelompok untuk menghias botol sesuai dengan imajinasi mereka.

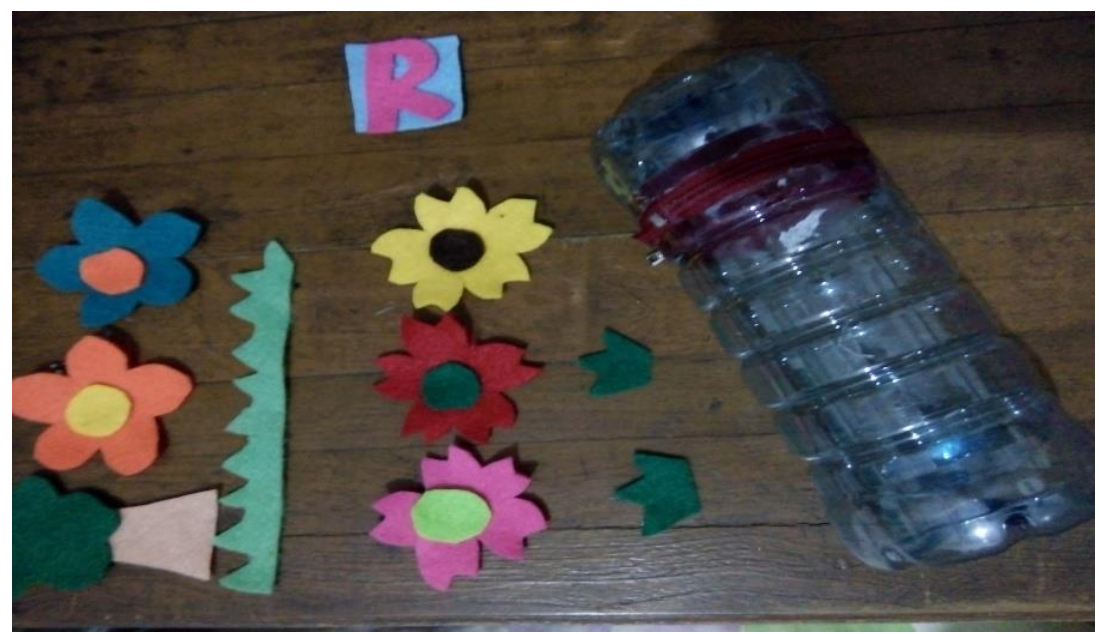

Gambar 3. Hasil potongan kain flanel salah satu kelompok 


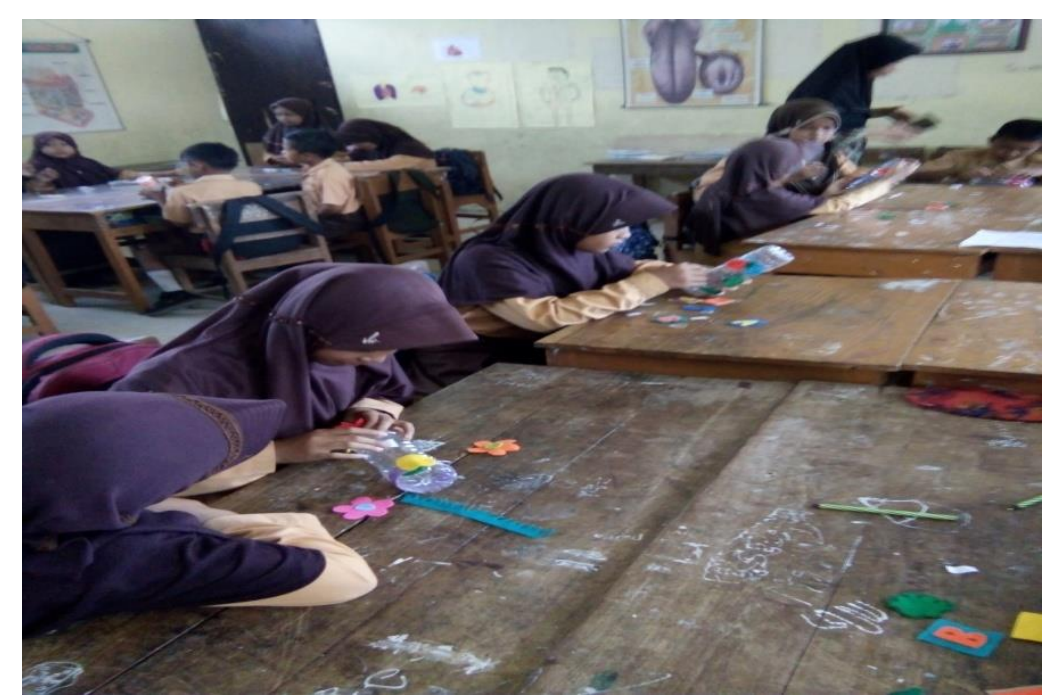

Gambar 4. Proses menempel kain flanel pada botol

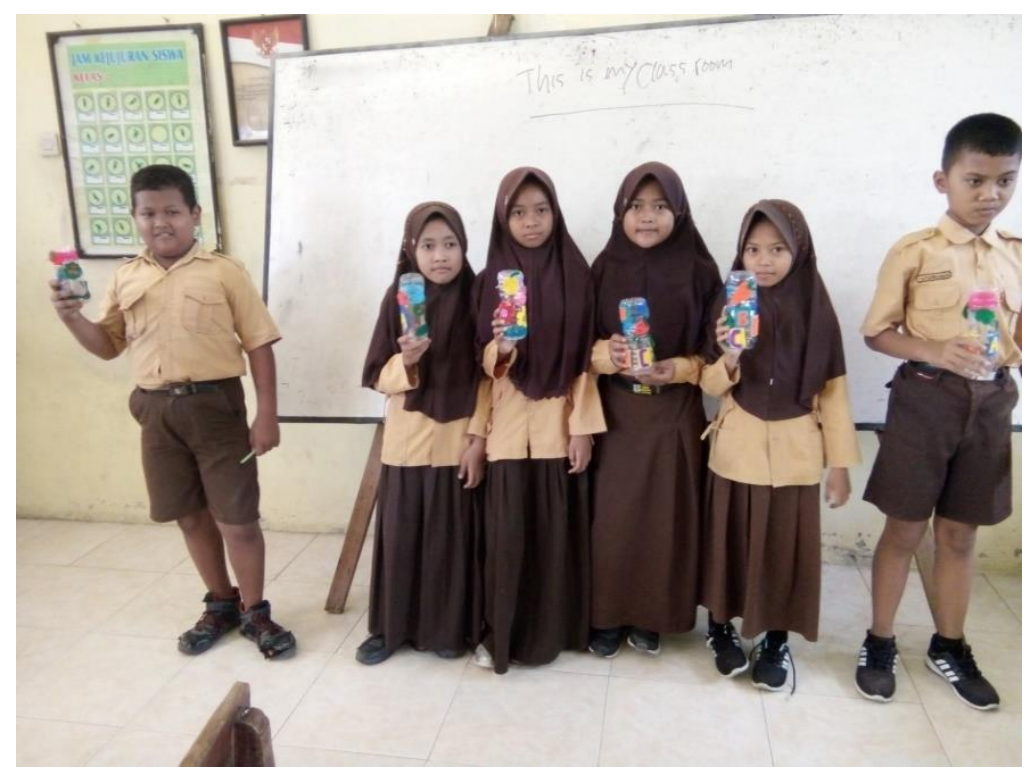

Gambar 5. Hasil botol bekas yang sudah dihias dengan kain flanel

Berdasarkan pengamatan selama kegiatan berlangsung yaitu pengabdian kepada masyarakat diperoleh hal-hal yang positif, yaitu : Siswa benar-benar mendengarkan materi yang disampaikan oleh Tim PKM mengenai cara membuat tempat pensil dari botol plastik, mulai dari pemotongan botol, pemasangan resleting sampai pada menggunting kain flanel sebagai penghias botol, siswa menunjukkan sikap positif dan rasa ketertarikan dalam pembuatan tempat pensil dari botol plastik, siswa mengikuti arahan dan mampu melakukan kerja sama yang baik dengan kelompoknya masingmasing sehingga mampu menyelesaikannya dalam waktu yang sudah Tim PKM tentutkan, siswa aktif bertanya secara bergantian apabila belum memahami dalam pembuatan tempat pensil dari botol plastik, siswa sejumlah 6 orang dalam satu kelompok selain bekerja sama dalam membuat tempat pensil disini Tim PKM memberikan kesempatan kepada masing-masing siswa untuk membuat tempat pensil 
secara individu dan siswa sadar akan pentingnya menjaga kebersihan lingkungan dari dampak negatif sampah plastik.

\section{Faktor pendukung dan penghambat}

Pelaksanaan kegiatan berupa pengabdian kepada masyarakat ini juga terdapat faktor pendukung dan penghambat. faktor pendukungnya adalah : Siswa sangat antusias mendengarkan ceramah dari Tim PKM, siswa menuangkan semua ide kretifnya melalui potongan-potongan kain flanel, dukungan dari pihak sekolah khususnya kepala sekolah beserta para guru terhadap kegiatan PKM ini.

Selain faktor pendukung yang dapat mempengarui kegiatan ini juga terdapat faktor penghambat, diantaranya adalah : Beberapa siswa yang kehabisan double tape untukmenempel, haltersebutmembuatkelas menjadi gaduh dan beberapa siswa membutuhkan bantuan Tim PKM untuk menempel bagian-bagian yang kosong.

\section{KESIMPULAN DAN SARAN}

Melalui kegiatan kreativitas dari botol bekas ini adalah bahwasannya masih banyak barang-barang bekas lainnya yang bisa dimanfaatkan kembali khususnya barang-barang yang terbuat dari plastik serta barang-barang bekas lainnya. Kegiatan yang bermanfaat ini juga menjadi contoh bagi sekolah agar lebih memberdayakan siswanya untuk lebih menuangkan ide-ide baru dalam memanfaatkan barang bekas sehingga menjadi sekolah yang memiliki siswa kreatif.

\section{DAFTAR RUJUKAN}

Sucipto, C. D. (2009). Teknologi Pengolahan Daur Ulang Sampah. Jakarta: Goysen Publising.

Familia, P. (2010). Warna-warni Kecerdasan Anak dan Pendampingnya. Yogyakarta: Kanisius.

Karuniastuti, N. (2016). Bahaya Plastik Lingkungan. Forum Teknologi. 3, 6-14. file:///C:/Users/1120/Documents/t2-Bahaya_Plastik---_Nurhenu_K.pdf.

Nugroho, P. (2013). Panduan Membuat Kompos Cair. Jakarta: Pustaka Baru Press.

Surono, U. B. (2013). Berbagai Metode Konversi Sampah Plastik Menjadi Bahan Bakar Minyak. Jurnal Teknik, 3, 32-40. file:///C:/Users/1120/Documents/05-ArtikelUntoro-Revisi.pdf.

Zulkarnain, I., \& Farhan, M. (2019). Meningkatkan Kreativitas Siswa Dengan Memanfaatkan Sampah Bekas Menjadi Barang Yang Bernilai Ekonomis. JABDIPAMAS Uurnal Pengabdian Kepada Masyarakat, 3, 25-31. 
134 J-Abdipamas, Vol. 4, No. 1, April 2020 